\title{
On Patriarchal Patenting and Brand Naming: Janet Evason and her Cluster Meet Frances Cauldhame
}

\author{
Sobre la Patentización Patriarcal y el Nombramiento de Marca: Janet Evason \\ y su Conglomerado conocen a Frances Claudhame
}

\author{
Juan Rafael Brenes Arrieta \\ Universidad de Costa Rica
}

\begin{abstract}
The following essay is a literary critique of the patriarchal dominion present in The Wasp Factory by Iain Banks, parallel to Joanna Russ's feminist arguments in The Female Man and the prism of brand naming and patenting in Modest_Witness by Donna J. Haraway. Such analysis proposes a postmodernist reading which rejects metanarratives to examine literature. Instead, this paper explores and evaluates the scientific and patriarchal power over the main character in The Wasp Factory by creating tropes inspired on The Female Man. The author suggests the reader to vanish the line which divides fiction and reality since the conflicts found in one plane are also seen on the other.
\end{abstract}

Keywords: feminism, fiction-reality, creative writing, patriarchy, cyborg

\section{Resumen}

El presente ensayo consiste en una crítica literaria del dominio patriarcal en The Wasp Factory de Iain Banks, junto al argumento feminista de Joanna Russ en The Female Man y la óptica de lo patentado en Modest_Witness de Donna J. Haraway. Dicho análisis propone una lectura postmodernista en la que se rechazan metarrelatos para examinar literatura. Este artículo explora y evalúa el poder científico y patriarcal sobre el personaje principal de The Wasp Factory al crear tropos inspirados en The Female Man. Se le sugiere a la persona lectora erradicar el límite entre ficción y realidad, debido a que los conflictos presentados en un plano se presentan de la misma manera en el otro.

Palabras clave: feminismo, ficción-realidad, escritura creativa, patriarcado, cíborg 


\section{Introduction}

$\mathrm{V}$ irginia Woolf stated on A Room of One's Own that "the truer the facts, the better the fiction" (p. 17). Literary critics, academics, and readers have diverse expectations about texts, but studies are often oriented to how literature works as a manifestation of reality and its purpose. Postmodernist theorist Lyotard posed his position against metanarratives and how they intend to provide isolated and canonical meaning to literature: prioritizing universal frameworks and excluding alternative discourses (quoted in Storey, 2001, p. 150). Moreover, researchers do not commonly make connections among stories and create tropes to figure them out; instead, they prefer to limit the analysis to the fictional work tackled with a determined theory. The Female Man written by Joanna Russ and published in the 1970s with The Wasp Factory created by Iain Banks and released in the 1980s are works of literature which readers have disregarded due to their complexity and intense storylines. Hence, the position adopted in this paper is of reading against the grain. As suggested by Graff, "what [literary] works prove to be about is not the truths and values that traditional interpretations have found in them, but rather the uncertain, indeterminate nature of their own status as representation" (p. 171). Based on the previous, this paper does not offer a traditional interpretation of a book (or two books) read from the prism of a single theory. What the following lines offer is an indeterminate study, possible thanks to the creation of tropes from characters of The Female Man to engage in analyzing and saving the protagonist of The Wasp Factory. My thesis is an alternative discourse, in opposition to metanarratives. By adopting the emancipating discourse of the four J's from The Female Man to instruct Frances from The Wasp Factory, this paper explores patriarchal dominion in both novels reflected on male brand naming and patenting into women to design and control them as their copyrighted cyborgs. Stories do not necessarily have to be manifestations of reality only; as I quoted Graff before, they contain a powerful independent status as representation. In other words, the tropes I conceive in this paper are not only useful to scrutinize The Wasp Factory but also the current patriarchal status in non-fictional worlds.

Frances' father from The Wasp Factory is taken as the dominant scientific figure in ownership of knowledge, Frank's body, and secrecy to see how his child was raised to become a hopeless nonexistent citizen, an insane killer, and hater of women. In this paper, Janet Evason and her cluster appear to Frank using Haraway's discourse of the FemaleMan(C) being her "agent, surrogate, and sister" (p. 70) to encourage him out of his delirium caused by a patriarchal figure. Therefore, the purpose of this paper is to make evident how The Female Man, having been written in the 1970 s can be adopted to tackle other fictional works, in this case The Wasp Factory and make connections with reality. That is, by arguing and demonstrating the ways Russ's novel contribute in patriarchal domination, the reader will get insight into how to critique male power in reality and fiction. This paper's general objective is 
to present The Female Man as a novel which serves to study the patriarchal domination in other literary works, for the purposes of critiquing male power which represses and controls women. Additionally, the three specific objectives of this article are: 1) to portray and criticize the male impression of women in both books aiming at understanding why men get to despise their opposite sex. 2) To scrutinize the relationship between brand naming and patenting in both novels and how the characters suffer from it with the intention of tackling why and how Frank was a designed cyborg to be repressed by patriarchal hierarchies. 3) To wipe out the line which divides fiction and reality. To achieve the previous, there is an invitation to Frances to be part of the deal (the business offered by the four J's) since this means inviting readers not to take for granted the interconnectedness among works of literature. By doing so, that who reads periodically will be able to project utopias to be pursued in our posthumanist world and to emancipate ourselves from patriarchy. This paper is divided into three sections. The following part consists of a literature review to explain to the reader the plot and major aspects of The Female Man and The Wasp Factory. The next section, which is the theoretical framework, is an account of significant aspects argued by Haraway in Modest_Witness@Second_ Millennium.FemaleMan_Meets_OncoMouse: Feminism and Technoscience to analyze the two novels. Finally, the last part of this paper is the appropriation of tropes from The Female Man to analyze The Wasp Factory and draw links to reality, as argued in the thesis.

\section{Literature Review}

The Female Man is the novel that contributes with the appropriation of tropes that makes this study possible. Joanna, Jeannine, Janet, and Jael are four women who share the same phenotypic traits but dwell in four parallel worlds. Three of them struggle with patriarchy in their universes, only one, Janet, comes from a world inhabited by women. When the four of them meet, they discover that their quest is to rid the world of patriarchal dominion. The following figure reveals specific traits that characterize each of the Js:

\section{The FemaleMan $(\mathcal{C}$}

\section{Jeannine}

From a United States that did not overcome the great depression in the 1930 s and World War II did not happen. She is a 1960 s young conventional woman, hoping to marry.

\section{Joanna}

She refers to herself as The Female Man. She is a 1970 s feminist living in the United States of reality.

\section{Janet}

From a future in which there are no men on Earth. She is from Whileaway and lives with her wife and daughter.

\section{Jael}

Alice-Jael Reasoner is from a farther future in which men and women are in war to gain power. 
By embodying the four main characters of the book into one emancipating figure, the projection of this article's thesis into The Wasp Factory will be explored. The four women are of course literary and fictional creations; but, for this paper, it is pertinent to grant them a higher level of meaning and give them access to dwelling the "real" world. Therefore, feminist and postmodernist traits of Joanna, Jeannine, Janet, and Jael, along with Haraway's arguments in Modest_Witness, are the major theoretical framework to conduct this analysis. In this way, it will be possible to achieve the purpose of taking Frances out of her misery and providing her the tools to go through a cathartic ritual in order to redesign herself as her own cyborg, as well as accepting her kin -composed by herself and the four J's. Each of the main characters from The Female Man will be guides; that is, each $\mathrm{J}$ will shed a light to analyze and instruct Frances into embracing her being a woman. More than just having been an assignment for a postgraduate seminar at the university, The Female Man is a work of literature so plausible and valuable that it serves to look into the way feminism is manifested in fiction and how fictional universes are not too far from non-fictional ones.

Banks' horror science fiction novel depicts the story of a young "boy," Frank, who grew up in a small island with his father. Frank does not exist in the social sphere since there are no records of his life for the State; he has no citizenship. While growing, Frank murders three people and one of his hobbies is to burn and kill animals and insects; this is dictated by his Wasp Factory. The main character's father had a study with prohibited entrance, but at the end of the novel Frank gets into this room and he discovers his father kept tiny fake genitals in a jar. Supposedly, Frank's crotch was bitten by a dog at a young age. His father told him this accident made him lose his genitals, but what he discovers is that he had always been a woman and his father's experiment all his life. Angus, the father, admits that Frank was actually Frances and he made her believe she was a boy to teach her how to hate women: Angus was a scientist and his aim was to wipe out the other sex. Frances's father had shaped her as his cyborg to obey his quest of loathing female humans. The Wasp Factory is not tackled on this paper from its beginning but its ending. Frances has a hard time accepting herself and she continues scorning women. The characters from The Female Man are taken as Frances's feminist saviors to instruct her into welcoming womanhood and join their kin. Once more, the intention from a literary criticism perspective here is to expose how patriarchy and scientific domination has affected literary characters and how this issue is not too far from reality.

Theoretical Framework. Haraway refers to herself as a modest witness who "lurks to be a spy and scout and a user" (1991, p. 6) at the end of the second Christian millennium. By the previous account, she intends to challenge the patriarchal practices of technoscience, rhetoric, and human appropriation. According to Haraway, these hierarchies of scientific knowledge and power manipulated by men's hands has aimed at covering democracy, social justice, economy, agriculture, 
medicine, labor, and the environment; working to privilege men and affect women and fellow minorities. Haraway critiques how at the end of the 1900s systematic male intelligence has patented, commercialized, and appropriated human, animal, and genetic materials (1991, p. 62). Such criticism can be transferred to The Wasp Factory through The Female Man since it mirrors Angus's appropriation of Frances and configuration of Frank as his prime cyborg. The cyborg, as put by Haraway (1991):

[...] is a cybernetic organism, a hybrid of machine and organism, a creature of social reality as well as a creature of fiction. [...] The cyborg is a matter of fiction and lived experience that changes what counts as women's experience in the late twentieth century. This is a struggle over life and death, but the boundary between science fiction and social reality is an optical illusion (p. 149).

The FemaleMan(C, as Haraway puts it to create a trope, is adopted as her "sister" because Russ's literary work "is the antithesis of a utopian or dystopian novel; the book, in form and content, is the disruption of the expectations of those and many other central gendered categories of linguistic production in white European and American writing technologies" (1991, p. 70) to produce the New World Order, Inc. In chapter one which is subtitled Syntactics, Haraway tackles the language and rhetoric of male technoscientific power, whereas in chapter two she defends the linguistic structure of The Female Man by being a complex book to be read but with an emancipating thesis at its ending. Taking the FemaleMan $\odot$ as a trope in the present research paper serves to explore how Angus produced Frank by patenting Frances and the ways she can adopt the FemaleMan $\left.{ }^{(}\right)$as her sister.

In "A Family Reunion," Haraway joins "in a family romance with the (onco)mice of all species and (female) men of all genders in the worlds of technoscience" (p. 119). She does this from the position of a modest witness, following her thesis and narrative, to disassemble patriarchy above science and knowledge. Again, the use of her tropes are of meaningful adaptation into this paper due to the figure of the FemaleMan(C) taken out of a literary work. This research will suggest and invitation to Frances and the reader to join the feminist boarding offered by Jeannine, Joanna, Janet, and Jael. "The fetus and the planet Earth are sibling seed worlds in technoscience" (Haraway, 1991, p. 174) as Frances was unfairly brought into the world for patriarchal patenting. Angus was in charge of cooking Frances's meals in order to feed her with hormones to appear more "masculine-like." Here is evident the visual alteration from a male to produce a modern gender which is above the "birth body" due to the fact that men are able to control the world (Haraway, 1991, p. 180). In other words, Angus intended to produce the "perfect" man to destroy women. Such assumption will be explored on this paper using Haraway's premises of visual technology to produce modern bodies.

The final chapter in Modest_Witness is of crucial reading to this paper's thesis since Haraway argues that "witnessing is a collective, limited practice 
that depends on the constructed and never finished credibility of those who do it, all of whom are mortal, fallible, and fraught with the consequences of unconscious and disowned desires and fears" (Haraway, 1997, p. 267). The disowned desires and fears of Frances on her game of being Frank and murdering insects, animals, and people made her adopt the position of hating women because that is what his father consciously designed her to do. The collective witnessing that the four Js experienced in the universe of The Female Man proposes to liberate Frances. Haraway also suggests that one should not take for granted the net and interconnectedness in which all humans (and I add here literary characters) belong to, so that readers will be fit to challenge, criticize, and tear down the New World Order, Inc. managed by patriarchy.

\section{Analysis}

Patriarchal dominion over "nature" and subjects. "Mother Nature" is a slogan commonly used in advertising and education to somehow promote the protection of natural resources. Under the aegis of taking nature as a metaphor to motherhood, scientific and political patriarchal powers have managed to excuse the exploitation of women in relation to our planet. Medieval philosopher Francis Bacon and so-called father of modern inductive scientific method, encouraged figures of power to advocate the control of nature for human benefit (Merchant, p. 68). The Baconian philosophy used the premise of "the secret womb" to connect women with nature: as women held mysteries due to their pregnancies, natural resources such as mountains and rivers contained secrets that had to be explored for human appropriation. It can be said that we owe Francis Bacon the current double-sided metaphor of "mother nature." The previous historical note is of pertinence since it links the patriarchal dominion over nature to what Angus, as a scientist, did to Frances.

When Old Saul savaged me, my father saw it as an ideal opportunity for a little experiment, and a way of lessening - perhaps removing entirely - the influence of the female around him as I grew up. So he started dosing me with male hormones, and has been ever since. That's why he's always made the meals, that's why what I've always thought was the stump of a penis is really an enlarged clitoris. Hence the beard, no periods, and all the rest (Banks, 1984, p. 181).

Assume Frances had been born as Frank; there would not have been a chance and a drive to manipulate his body. But because Frances was born a girl and her father desired to make women disappear, from a position of a scientist, he was "allowed" and "privileged" to conduct his experiment with his daughter. The appropriation of women and nature depicted in The Wasp Factory comes from Baconian beliefs that are still put into practice. Though, the importance of bringing in Bacon to the discussion is to introduce and disclose the prevailing of dominion over nature and women mirrored in modern technoscience. For instance, in Screening the Body, Cartwright deals with the justification of "healthy" and "normality" in science to embody perfectness and modified genders (qtd. in Matrix, p. 243). In the next part of the 
analysis I connect this idea Angus had of appropriating women (Frances) and nature (her context and social practices) for scientific purposes (creating the perfect "body") to what is currently occurring in technoscience.

Male brand naming, patenting, and copyrighted cyborgs. The previously argued patriarchal appropriation of women and nature links to the male brand naming and patenting going on nowadays. As it was mentioned before in the theoretical framework, such patenting benefits men and affects women in several ways. In reality it can be seen how birth control pills, cancer treatments, among other products placed in the market by the pharmaceutical industry, have side effects which harm the person who takes them. Angus brand named and patented Frank to be his copyrighted cyborg. Frances fears the world and dwells in uncertainty because she has never felt a girl. Having been Frank gave her identity and purpose for the first young years of her existence. What is wrong here is that such ownership Frank thought he had of himself was not his, but his father's. The Female Man reworks and reestablishes the idea of copyrighted material, brand naming, and patenting. The book and its characters educate the reader to expropriate the patriarchal threads which manipulate subjects for the benefit of men. Alice-Jael Reasoner offers Jeannine, Joanna, and Janet an invitation to take a position of power and claim an emancipation of all male domination. Jael created a cyborg which she controls and uses for her pleasure, she patented and brand named him as Davy. She tells him when to sleep, when to have sex with her, and when to work. "Alas! Those who were shocked at my making love that way to a man are now shocked at my making love to a machine; you can't win" (Russ, 1975, p. 200). The creation of Davy places Jael at the same level of ownership and power that Angus had after designing Francis; but, there is a significant difference. Davy is and has always been a robot with no given identity: he has no consciousness or unconsciousness and he is not a victim suffering from the consequences of his acts. While manipulating Frances meant deceive a human being, a child, for the purposes of becoming a man to harm, not to do any good. Placing The Female Man with The Wasp Factory gives Frances a chance to rework and reestablish herself as her own. The last and following part of the analysis consists of meeting the two fictional universes to provide Frances her acceptance and liberation.

Interconnectedness of fiction and reality to emancipate. I would like to start this last part with a brief narrative of my creation. As a disclaimer, the following lines consist of a fictional piece added for the purposes of analysis. Since this paper is a literary criticism article based on The Female Man and The Wasp Factory, fiction should not be taken for granted, let alone fictional writing conceived out of two novels. This tale is called "Janet Evason and Her Cluster Meet Frances Cauldhame":

Frances held some of the remaining pieces of the wasp factory in her hands, others were spread around her. Shortly after discovering her truth, she ran upstairs and destroyed the clock which used to 
reveal the fate of her victims, more like the manner they would die. No more victims of arson, stabbing, beheading, or poisoning, just to mention a few creative ways of murdering. With her right hand she gripped a broken glass, causing a current of thick blood run through her arm. She unbuttoned her trousers and dropped them to her ankles. Slowly she removed her underwear, though she was reluctant to look at herself. Then she realized this needed to happen, she had to see it for herself, to figure out whatever she was, what she had been made. She saw her genitals and despised herself. She hated the effort she had been making her entire life to avoid thinking how much she scorned her existence: her hidden existence. Before she attempted to cut her genitals, she saw her goddess on the floor. She put her underwear and trousers back on and moved to the dead wasp settled in front of her. Frances took it and looked at it with admiration one more time. The dead wasp laid on the tip of her left thumb when it occurred. At first, Frances thought it was an earthquake, but such an event would never cease gravity to exist. The wasp was then hovering by her eyes, the wood panel ceiling started shaking, broken scraps of the factory and her body were slowly coming up, leaving the floor. A bright flash hit the room, the wasp blasted, and four women appeared. Frances fell down, as the objects around her did. "Sisters, she is younger than we thought, how lovely!" Yelled Jeannine. "Hush," Joanna exclaimed, "the creature is clueless about our coming here." "More like the way we got here," Janet complained, "I'll never get used to this time-parallel-universes-traveling lifestyle, I miss Whileaway." Frances stood up and asked the strangers, from whom she noticed a certain physical similarity, who they were. "We," started Jael, "are your saviors." Frances did not say anything but grasped the glass on her hand in a stronger way. How could four unknown women claim to be her saviors? Women, she hated women. But she was one. She was a woman, a female youngster. Did she truly hate herself? Or did she hate the version of herself configured by her father? "But I've killed, I've harmed innocents, I'm not sure if I deserve saving," cried Frances. There was a moment of silence. Janet offered her hand. Frances released the glass she held, dropping it, shattering a little bit of blood through the floor and the walls, one drop even stained Jeannine's blouse. "There's nothing to be afraid of, child," said Jael in a terrifying sensual tone. Frances extended her hand. Janet took it and examined the blood and the deep cut on the child's palm. She then held Frances's hand, as the other Js formed a circle around. The five women disappeared, leaving the room in an unreal and dramatic fashion.

What I did above was my way of making connections among the two novels; it was my reading against the grain, my avoiding metanarratives by not studying The Female Man and The Wasp Factory from the lens of one 
single theoretical approach. The previous tale is a brief postmodernist utopia created for empathy towards Francis, coming up with interconnectedness in fiction to emancipate her. As stated at the beginning of the paper, one of its specific objectives is to erase the limit between fiction and reality for the purposes of inviting Frances to join the kin extended by the four J's.

To finish this analysis, Russ argues that "utopias are not embodiments of universal values, but are reactive; that is, they supply in fiction what their authors believe society... and/or women, lack in the here-and-now" (qtd. in Silbergleid, 1997, p. 161). The thesis offered by Silbergleid contributes on this study since having the four Js inviting Frances and the reader to liberate from patriarchy, challenge, and criticize it, is a utopian practice I am proposing. Using two novels under the theoretical framework of a modest witness and wiping out the line which divides fiction and reality is granted as utopia since it proposes a world with no patriarchy and humane kinship.

\section{Conclusion}

Gendered authorities might overlook the present paper due to the criticism addressed to how literature postulates ways of disapproving patriarchy in fiction and in nonfiction. Therefore, I regard this analysis as a postmodern indeterminate text which contributes in extending alternative ways of reading and conducting literary interpretation. Frances must not be only taken as a fictional character, Frances is present in reality. The victims of patriarchy, be it women, children, poor people, queer people, among others, are the Frances of nonfictional worlds. As Haraway adopted the FemaleMan(C) as her sister, this trope was adopted in this paper as the four Js who liberated Frances. The appropriation of male power following the fallacy of "mother nature" in "real life" will continue. Hence the reason why I encourage the reader and critic to move forward making connections between literature and facts of existence to tear down patriarchal ruling. One must be critical about the male brand naming and patenting posed in society because being ignorant to that will not make expropriation achievable. Copyrighted cyborgs will not cease to exist immediately since that implies an analytical introspection of ourselves. We are all cyborgs but are we copyrighted to somebody or something else? Perhaps moving forward exploring literature and recurring to their disclosures will make humans pursue emancipation. What if now we say "the more complex fiction is, the more possibilities for approaching reality appear?"

\section{Bibliography}

Banks, I. (1984). The Wasp Factory. New York: Simon and Schuster.

Bartsch, I., \& Lederman, M. (2003). The Gender and Science Reader. London: Routledge.

Haraway, D. (1991). Simians Cyborgs and Women The Reinvention of $\mathrm{Na}$ ture. New York: Routledge. (1997). Modest_Witness@Second_ Millennium.FemaleMan_Meets_ OncoMouse: Feminism and Technoscience. New York: Routledge. 
Lentriccia, F. \& McLaughlin, T. (eds.). Silbergleid, R. (1997). Women, Uto(1995). Critical Terms for Literary Study. 2nd ed. Chicago UP.

Matrix, S. (2001). Cyberfeminism and Technoculture Studies: An Annotated Bibliography. Women's Studies Quarterly. 29, 3/4. pia, and Narrative: Toward a Postmodern Feminist Citizenship. Hypatia. 12, 4.

Storey, J. (2001). Cultural Theory and Popular Culture: An Introduction. 3rd edition. London: Pearson.

Russ, J. (1975). The Female Man. Woolf, V. (2014). A Room Of One's Boston: Beacon Press.

Own. London: Penguin Classics. 